\title{
Investigation of Climate and Land Use Policy Change Impacts on Food Security in Eastern Sudan, Gadarif State
}

\author{
Yousif Elnour Yagoub ${ }^{1,2,3^{*}}$, Zhongqin Li ${ }^{1}$, Omer Said Musa ${ }^{2}$, Muhammad Naveed Anjum ${ }^{4}$, \\ Feiteng Wang', Zhang Bo ${ }^{3}$
}

${ }^{1}$ State Key Laboratory of Cryospheric Sciences/Tian Shan Glaciological Station, Northwest Institute of Eco-Environment and Resources, CAS, Lanzhou, China

${ }^{2}$ Department of Forest Protection and Conservation, University of Khartoum-Faculty of Forestry, Shambat, Sudan

${ }^{3}$ College of Geography and Environmental Science, Northwest Normal University, Lanzhou, China

${ }^{4}$ Division of Hydrology Water-Land Resources, Northwest Institute of Eco-Environment and Resources, CAS, Lanzhou, China

Email: *yousif@lzb.ac.cn, *yousifelnouryagoub@yahoo.com

How to cite this paper: Yagoub, Y.E., Li, Z.Q., Musa, O.S., Anjum, M.N., Wang, F.T. and Bo, Z. (2017) Investigation of Climate and Land Use Policy Change Impacts on Food Security in Eastern Sudan, Gadarif State. Journal of Geographic Information System, 9, 546-557.

https://doi.org/10.4236/jgis.2017.95034

Received: July 10, 2017

Accepted: September 10, 2017

Published: September 13, 2017

Copyright $\odot 2017$ by authors and Scientific Research Publishing Inc. This work is licensed under the Creative Commons Attribution-NonCommercial International License (CC BY-NC 4.0). http://creativecommons.org/licenses/by-nc/4.0/

\begin{abstract}
The aims of this research were to investigate the impacts of climate variations on land use policies, food security and vegetation cover in Gadarif State (eastern Sudan) during 1961 to 2013. Analysis of precipitation and temperature time series revealed that the annual precipitation was decreasing while the temperature was increased in the study area. Precipitation was decreasing at a rate of $-50.3 \mathrm{~mm} / 10 \mathrm{a}$, while the temperature was increasing at a rate of $0.02^{\circ} \mathrm{C} / 10 \mathrm{a}$. The result of both SPEI and SPI showed that the Gadarif State has been changed to a high frequency of drought during 1961-2013. Sorghum yield showed a significant positive relationship with precipitation during July and October ( $\mathrm{CC}=0.364$ and 0.321 , respectively), moreover, a significant positive relationship between Sesame yield and precipitation was observed during July $(\mathrm{CC}=0.335)$. A significant negative relationship between Sorghum yield and mean temperature was observed during the rainy season (July to October) with CC $=-0.278$. The yield productivity of Sorghum and Sesame had decreased significantly (from more than $800 \mathrm{~kg} / \mathrm{ha}$ in the 1960 s to less than $200 \mathrm{~kg} / \mathrm{ha}$ in $2000 \mathrm{~s}$ for Sorghum, while $500 \mathrm{~kg} / \mathrm{ha}$ in $1960 \mathrm{~s}$ to $100 \mathrm{~kg} / \mathrm{ha}$ in $2000 \mathrm{~s}$ for Sesame). The Mechanized Rain-fed Agriculture (MRA) area of Sorghum and Sesame in the Gadarif State had been increased from $1,058,241$ ha to $2,799,655$ ha during 1961 to 2013 . Thus, we ultimately suggest that in the Gadarif State, policy makers must strive for an increase in yield per unit area by using sufficient fertilizers along with the gradual increment in tendencies of grain production through expansion of the
\end{abstract}


cultivated area.

\section{Keywords}

Climate Change, Land Use Policy Change, Food Security, Gadarif State

\section{Introduction}

Climate change is attributed directly or indirectly to human activity that alters the composition of the global atmosphere and which is as well as natural climate variability observed over comparable times [1]. Global mean temperature has increased by $0.85^{\circ} \mathrm{C}$, over the period 1880 to 2012 and this increase in temperature is likely due to human activities that have increased the concentrations of greenhouse gases to unprecedented levels [2]. In Africa, Sudan is one of the driest countries. It also has most variable rainfall in the continent. Extreme years "either good or bad" are more common than average years [3]. In Sudan, the drought cycles have resulted a severe negative social and economic impacts, including human and livestock fatalities and resettlement of about three million people near the Nile River. Decreasing of the palatable forbs led to appearing the invader grasses, which are unpalatable to livestock. The share of agriculture in GDP \% of Sudan has a decreasing trend between 1965 and 2013. Furthermore, the share of agriculture in GDP \% of Sudan is a decline in many years which is correlated with a low precipitation and high temperature [4]. The share of agriculture in GDP of Sudan was significantly decreased from $42 \%$ in 2000 to $29 \%$ in 2014 [5].

Gadarif State underwent a highly significant increase of maximum temperature during summer, winter and autumn [6]. The vegetation cover was cleared changing of land use cultivation of crops, as the forest lands are usually characterized by high fertile and suitable for growing crops, which becomes as an appetizer for farmers to clear trees. The expansion of mechanized rain-fed schemes, illicit cutting for charcoal and firewood, traditional rain-fed agriculture and over grazing were causes of deterioration that affected ecological equilibrium and biodiversity [7]. Land mismanagement, due to Mechanized Rain-fed Agriculture (MRA), led to soil deterioration and change in soil physical properties. Consequently, crop yield, socioeconomic and environmental settings were adversely influenced [8]. The MRA in Gadarif State is the most important area in the country since it contributes significantly to the total food production for the majority of inhabitants [9]. Loss of soil fertility and rainfall variability is among such factors. Crops yields are declined level of significance, which indicates a significant decline in soil fertility [10].

Previously, [11] reported some measures for improvement of rain-fed agriculture in central Sudan, according to the priority should be given to measures that will increase the soil fertility; and further investigate the impact of meteoro- 
logical drivers on crop production in Sudan [12]. As recommended by [4], a creating more livelihood options to adapt to the local weather with an understanding of local community and their sharing planning policies for effective adaptation strategies with the impacts of climate change in Sudan. As reported by [13], the rain-fed agriculture is depended on a large extent on smallholder, subsistence agriculture is a source of livelihood of the most population in sub-Saharan Africa. A 38\% of the population in sub-Saharan Africa lives in drought-prone dry lands.

The objectives of this research were to investigate influences of climate change on food security and vegetation cover, a number of specific objectives were formulated to assess climate change in Gadarif State considering the period of 1961 to 2013 in the light of the status.

\section{Material and Methods}

\subsection{Study Area}

Gadarif State is located in latitudes $12^{\circ} 48^{\prime}$ and $15^{\circ} 50^{\prime} \mathrm{N}$ and longitudes $33^{\circ} 40^{\prime}$ and $36^{\circ} 47^{\prime} \mathrm{E}$, covers an area of about 6225794.91 ha (Figure 1 ). The estimated population of Gadarif State is $1,348,378$ people [14]. The state is a semi-arid climatic condition with an aridity index ranging from 0.2 to 0.4 [15]. The average mean annual temperature of Gadarif State is $30^{\circ} \mathrm{C}$. Gadarif State receives the highest temperature in April and May.

\subsection{Data Collection and Analysis}

Monthly and annual precipitation and temperature data of Gadarif State were collected from the Sudan Meteorological Authority. Figures 2(a)-(e) showed the annual precipitation and temperature, in addition, monthly precipitation and temperature of the rainy season (July to October) during 1961-2013. This study consisted of two types of data. The primary data involves climatic data for the years 1961-2013. Vegetation and crop yield in eastern Sudan rain-fed agriculture would highly depend on the state of the climate, particularly precipitation
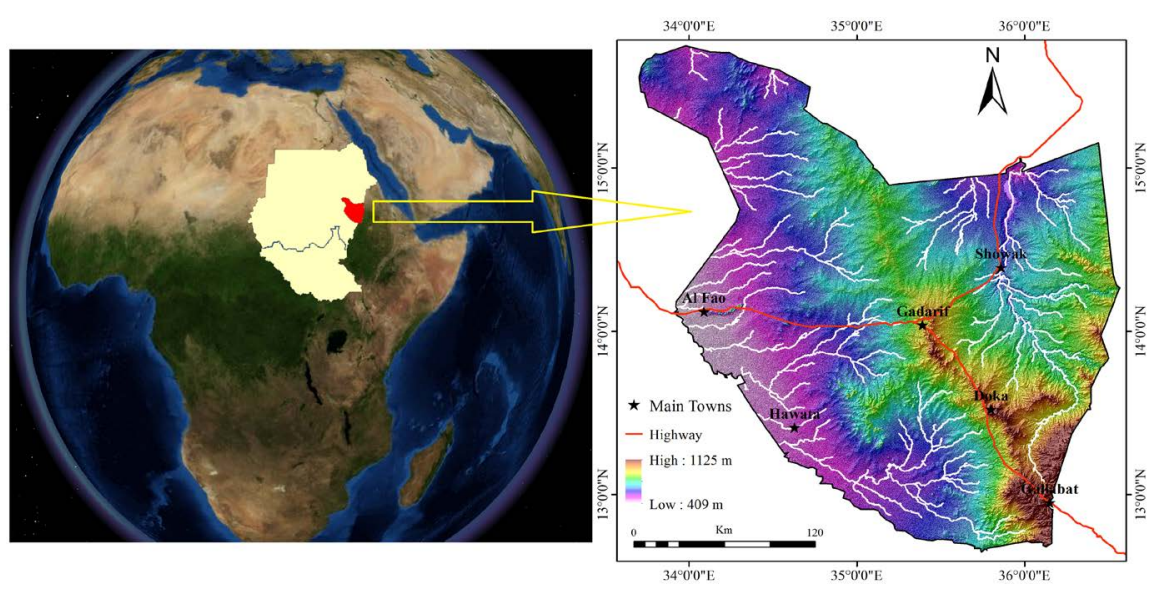

Figure 1. Study area Gadarif State. 

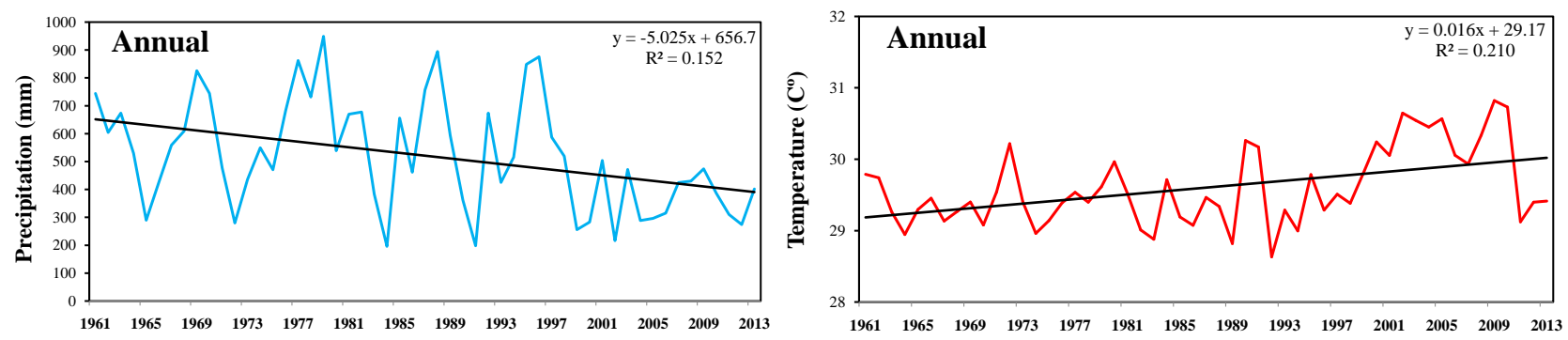

(a)
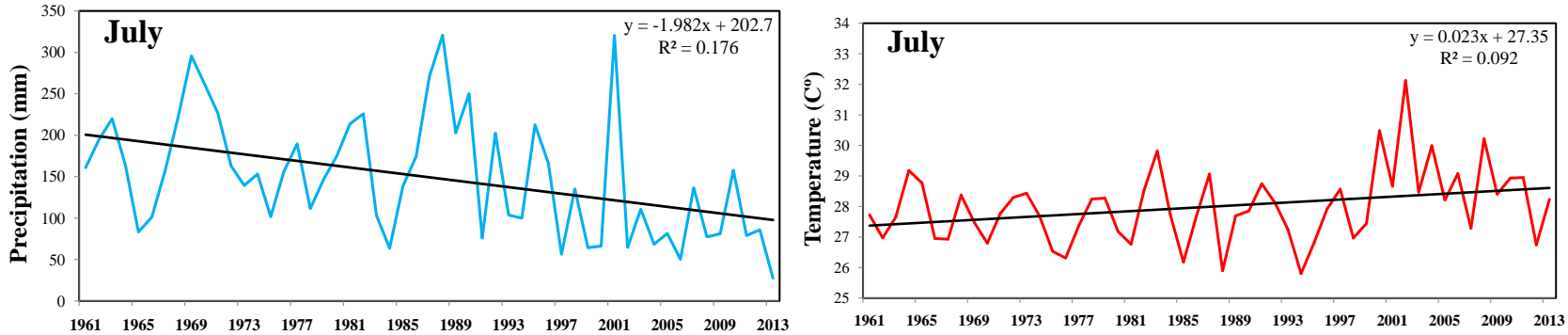

(b)
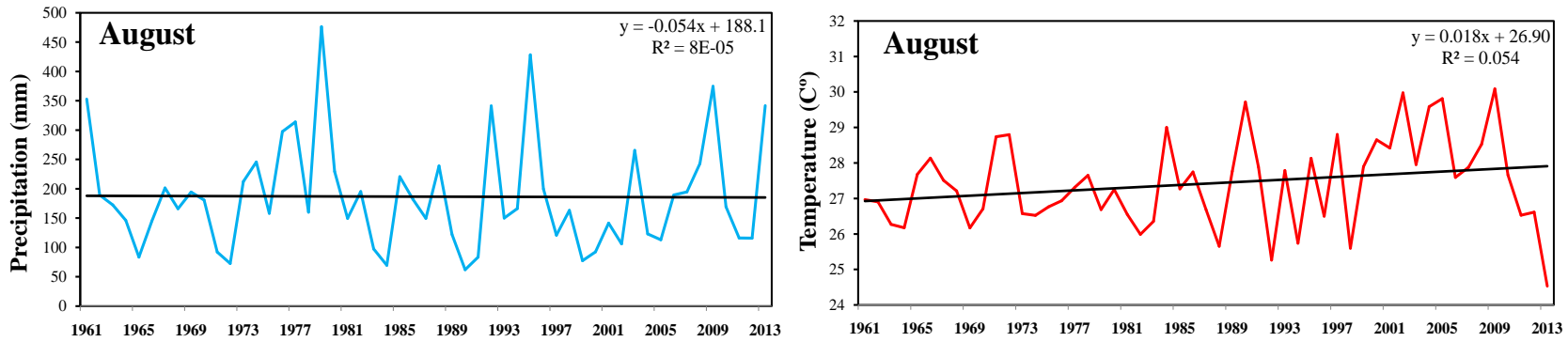

(c)
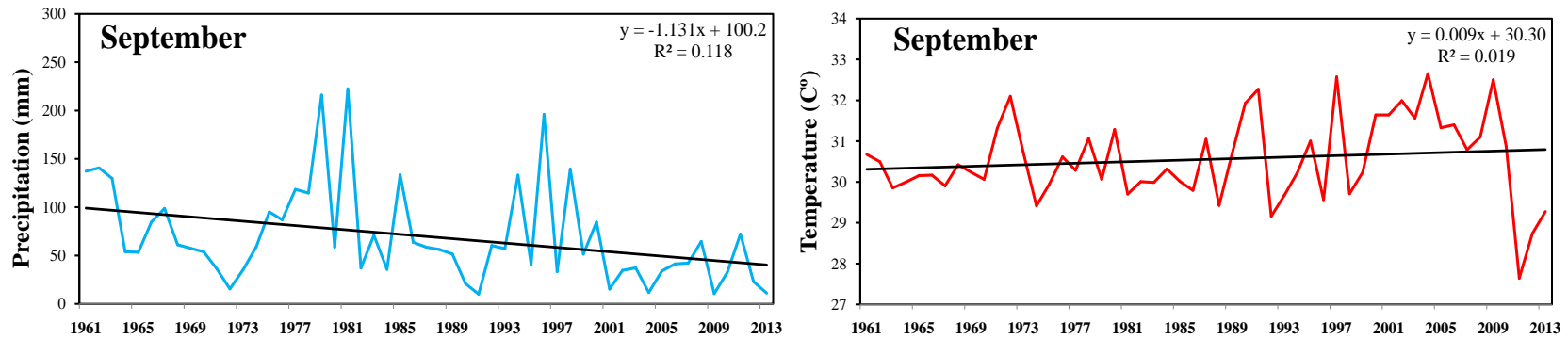

(d)
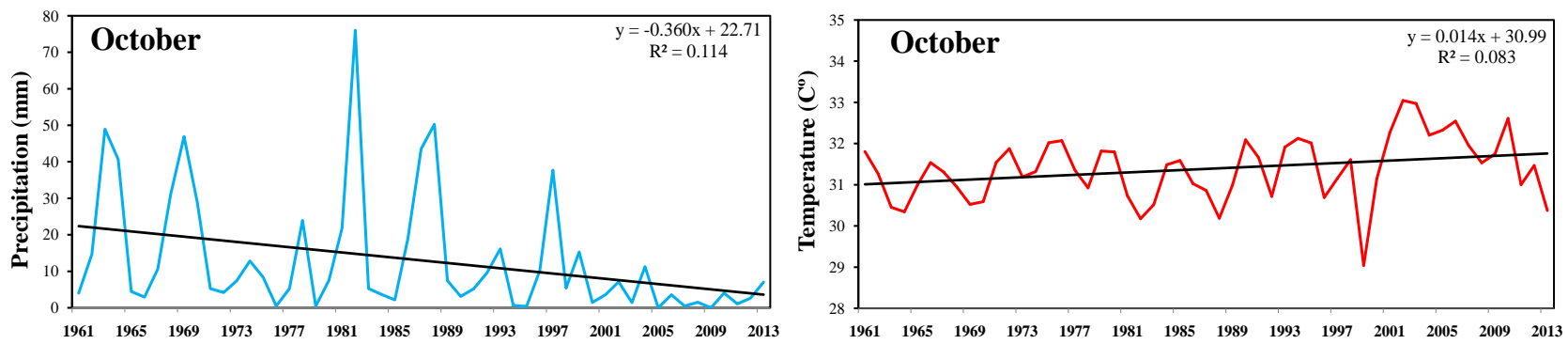

(e)

Figure 2. The mean annual precipitation and temperature. In addition, monthly precipitation and temperature of July to October in Gadarif State during 1961-2013. 
variables [16]. In 2009, the Sorghum productivity was a decline of $42 \%$ of the normal yield; also, the annual precipitation amount was $87 \%$ of the normal [17]. Also, we calculated the Standard Precipitation Evapotranspiration Index (SPEI) and Standard Precipitation Index (SPI) at scale of 1-, 12-, 24-, 36- and 48-month scale to investigate the drought categories according to [4] and [18], no drought $>-0.5$; mild drought -0.5 to -1.0 ; moderate drought -1.0 to -1.5 ; severe drought -1.5 to -2.0 ; extreme drought $<-2$.

\subsection{Food Security}

Food security data of Gadarif State during 1961 to 2013 was the crop yield of Sorghum (Sorghum bicolor) and Sesame (Sesamum indicum). Moreover, research documents, national and international relevant projects documents, related official records and annual reports were used as supporting data.

\section{Result and Discussion}

\subsection{Climate Data and Drought Indices Analyses}

Figures 2(a)-(e) showed the variations of annual and monthly precipitation and temperature anomaly in Gadarif State for the 53 years. Annual precipitation and temperature anomalies showed great fluctuations all over the Gadarif State. By alternating the fluctuations of positive and negative anomalies, the most negative precipitation anomalies periods have been recorded, for example, in 1965, 1973, 1983, 1984, 1990, 1991, 1999, 2000 and 2002 (Figure 2(a)). Wet years were also noticed for example, in 1969, 1970, 1977, 1979, 1987, 1988, 1992, 1995 and 1996. Likewise, temperature showed fluctuations with a generally increasing trend in 1972, 1980, 1984, 1990, 1991, 2007 and 2008. The analysis of precipitation and temperature data for the Gadarif State showed that there was a steep decreasing trend in annual precipitation and increasing trend in temperature. The precipitation was decreasing at the rate of $-50.3 \mathrm{~mm} / 10 \mathrm{a}$, while the temperature was increasing at the rate of $0.02^{\circ} \mathrm{C} / 10 \mathrm{a}$. The monthly precipitation showed a declining trend rate of $-19.8 \mathrm{~mm} / 10 \mathrm{a},-0.5 \mathrm{~mm} / 10 \mathrm{a},-11.3 \mathrm{~mm} / 10 \mathrm{a}$ and -3.6 $\mathrm{mm} / 10 \mathrm{a}$ for July, August, September and October, respectively, while temperature showed an increasing trend at a rate of $0.02^{\circ} \mathrm{C} / 10 \mathrm{a}, 0.02^{\circ} \mathrm{C} / 10 \mathrm{a}, 0.01^{\circ} \mathrm{C} / 10 \mathrm{a}$ and $0.01{ }^{\circ} \mathrm{C} / 10 \mathrm{a}$ for July, August, September and October, respectively. [19] found an increasing trend in mean, maximum and minimum temperature over the whole Sudan in line with a significant decline of precipitation over the northern half of Sudan. As reported by [17], Gadarif State had observed a significant climate warming, increased precipitation variability and seasonality and intensified aridity conditions from 1941 to 2009.

Figure 3 showed that the SPEI and SPI drought indices have a temporal frequency can enabling the detection of persistent dry and humid period's pattern. The SPEI index at 12-month showed that a high frequency of drought in 1972 1973, 1984, 1991-1992 and 2000-2011, while SPI 12-month shows a high frequency of drought in 1966, 1972-1973, 1984, 1986, 1991-1992 and 1999-2013. In 

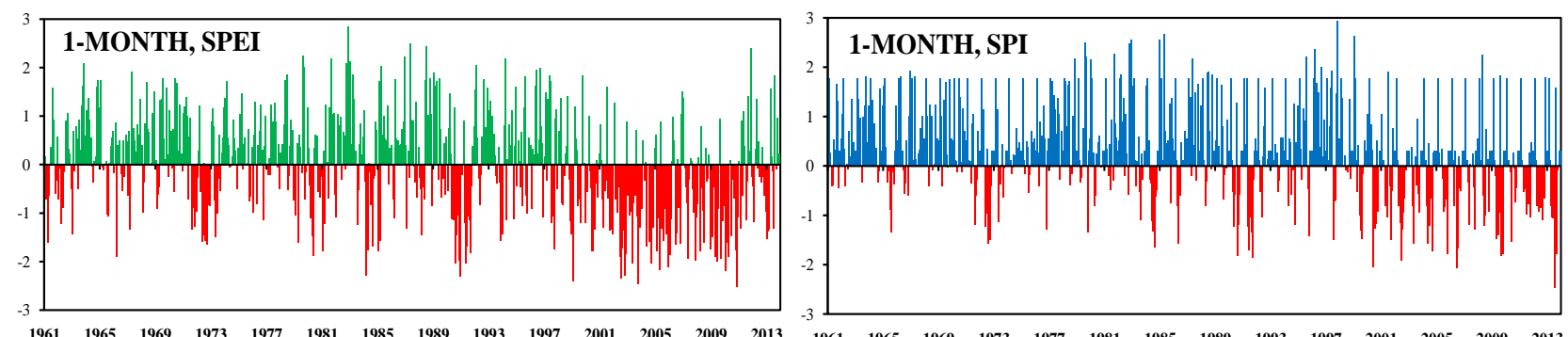

(a)
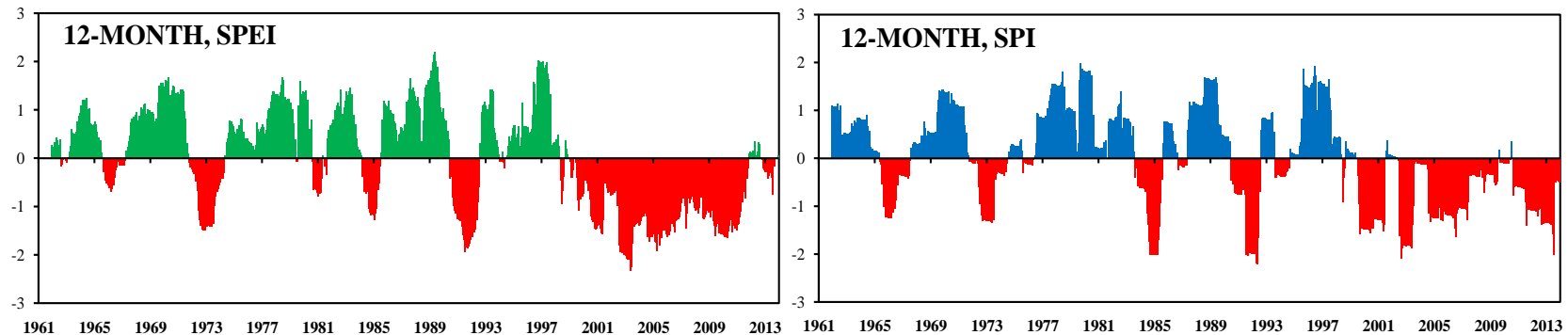

(b)
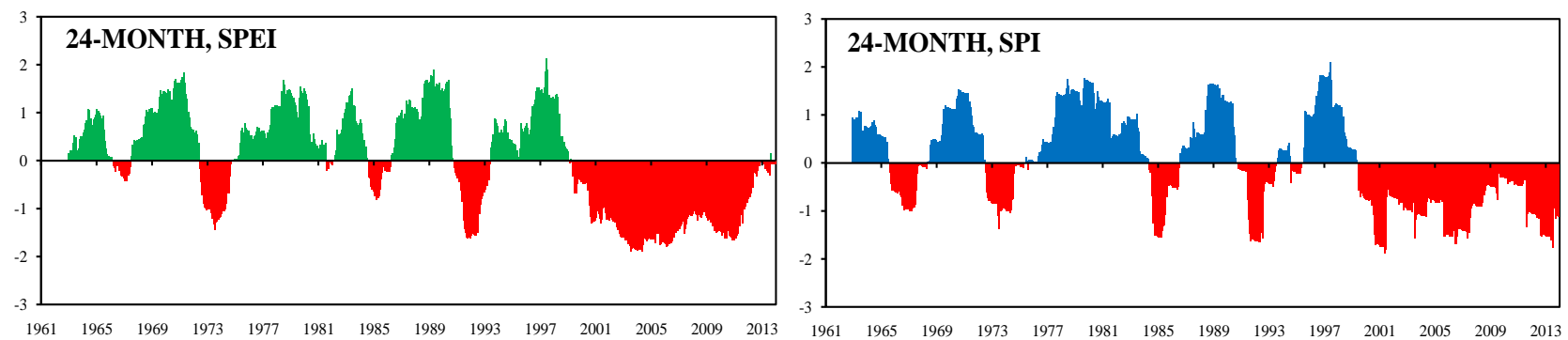

(c)
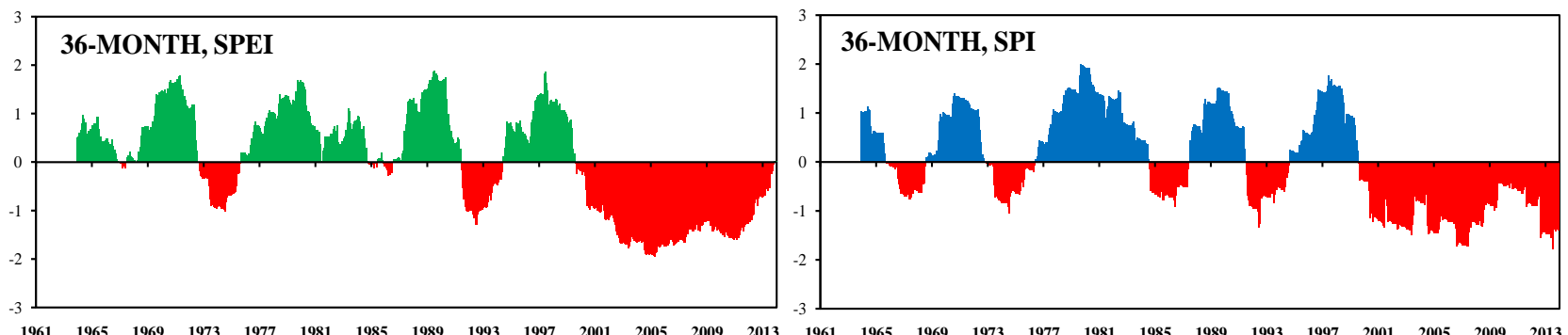

(d)
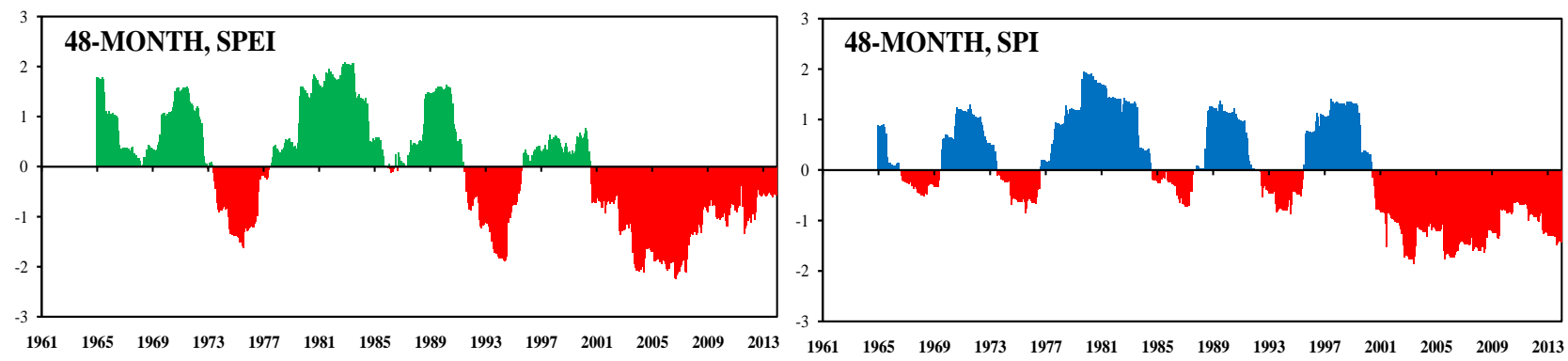

(e)

Figure 3. Distribution of SPEI and SPI values at 1-, 12-, 24-, 36- and 48-month time scale in Gadarif State during 1961-2013. 
addition, both SPEI and SPI showed that the Gadarif State from 1999 to 2011 was been changed to a high frequency of drought. As reported by [19], Gadarif State showed an extreme drought in 984 and 1990; severe drought in 1991 and 2005; moderate drought in 2000, 2001, 2002, 2007 and 2008; mild drought in 2006. In addition, [4] and [18] showed that the climate of Gadarif State has a big changing from humid to extreme drought in a period of 1961-2013.

\subsection{Food Security Analysis}

Figure 4 showed that the MRA area of two main grain crops (Sorghum and Sesame) in Gadarif State had increased from 1,058,241 ha to 2,799,655 ha during 1961 to 2013. The increased scale of MRA in the Gadarif State was started in 1945 when the Colonial British Government decided to cultivate the cracking clays of Central Sudan in order to satisfy the food demands of army units in East Africa [20]. In the 1960s, massive land areas in Sudan were cleared for crop cultivations. Consequently, at the end of the 1970s to the early 1980s, most of the lands were changed to MRA [21].

Projected climate change impacts and growing socioeconomic pressures on agriculture highlighted the intensification of desertification of arable areas. Moreover, the humid agroclimatic zones are likely to shift southward, rendering areas of the north increasingly unsuitable for agriculture [22]. The expansion of agricultural lands due to the favorable government farming policy is among the main reasons behind the land use changes in East Africa [23]. Figure 5(a) Figure 5(b) captured that the yield productivity of Sorghum and Sesame. It was observed that the yields of both crops (Sorghum and Sesame) were decreased significantly from more than $800 \mathrm{~kg} / \mathrm{ha}$ and $500 \mathrm{~kg} / \mathrm{ha}$ in the 1960 s to less than $200 \mathrm{~kg} / \mathrm{ha}$ and $100 \mathrm{~kg} / \mathrm{ha}$ in $2000 \mathrm{~s}$, respectively. Sustainability of agricultural practices in rain-fed areas is a big challenge for the production of food in Gadarif State as well as other areas of Sudan. Precipitation is the main irrigation source for crops cultivated in the rainy season (July to October). Table 1 showed that the correlation coefficients of Sorghum and Sesame yields with precipitation and temperature in Gadarif State during 1961-2013. The results explored that there was a significant positive relationship between Sorghum yield and precipitation

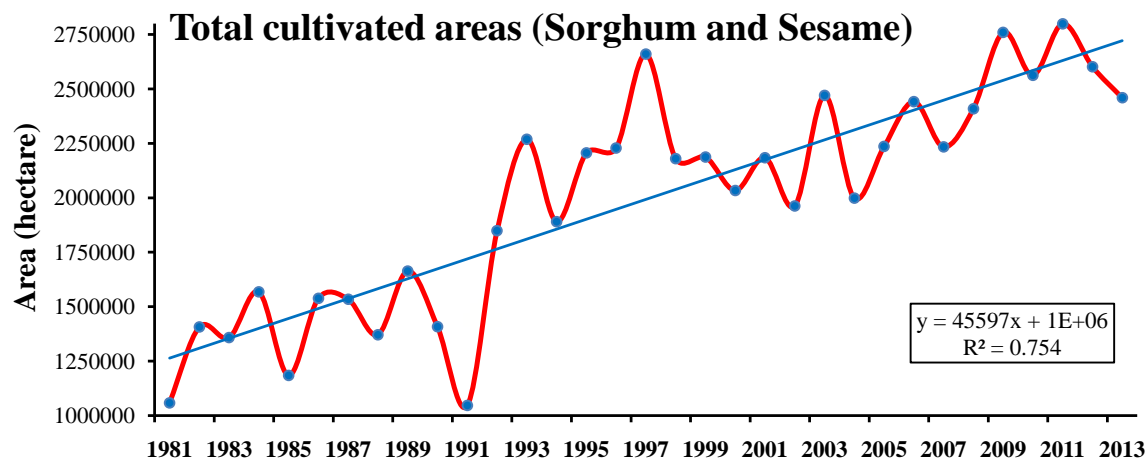

Figure 4. Total areas of MRA during the period 1981-2013. 


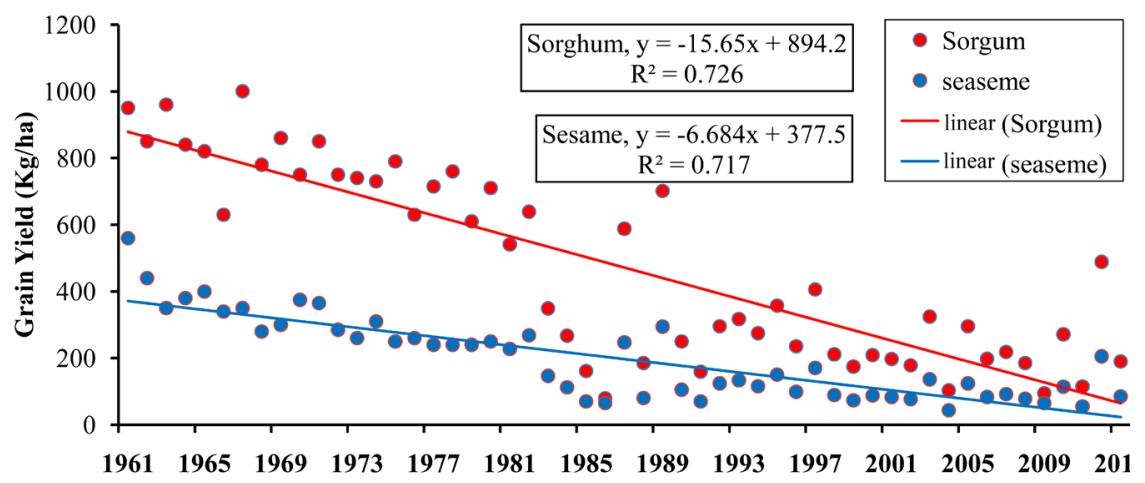

(a)

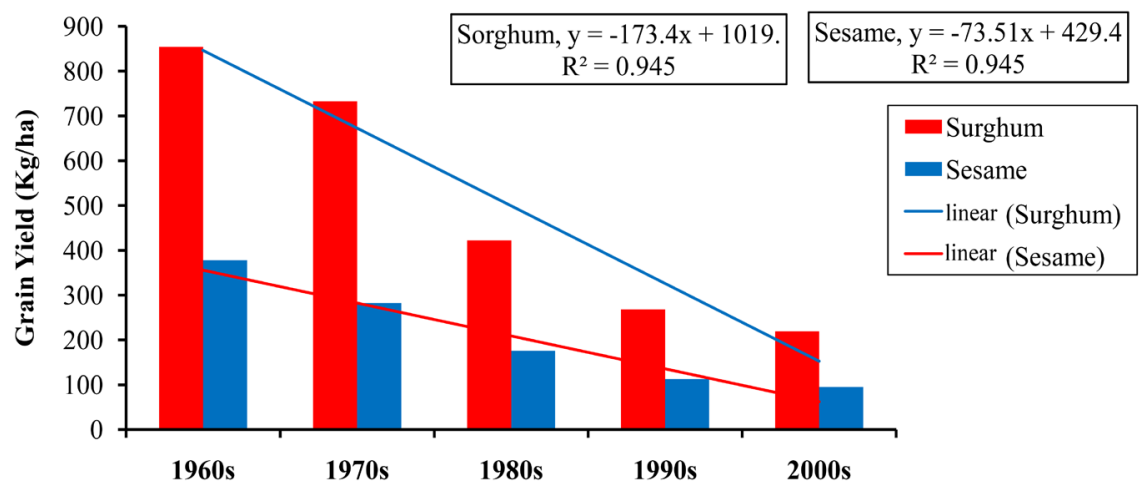

(b)

Figure 5. (a) (b) Yield production of the main two grain types of food security in Gadarif State, which they depend on rainy season during 1961-2013.

Table 1. Correlation coefficients of sorghum and sesame yield production with precipitation and temperature by using SPSS software in Gadarif State during 1961-2013.

\begin{tabular}{cccc}
\hline & Month & Precipitation & Temperature \\
\hline Jul & $0.364^{* *}$ & -0.248 \\
Sorghum & 0.058 & -0.25 \\
& Sep & 0.251 & -0.133 \\
& Oct & $0.321^{*}$ & 0.131 \\
& Jul to Oct & $0.329^{*}$ & $-0.278^{*}$ \\
Sesame & Jul & $0.335^{*}$ & -0.233 \\
& Aug & 0.069 & -0.233 \\
Sep & 0.254 & -0.132 \\
Oct & 0.053 & -0.192 \\
& Jul to Oct & $0.318^{*}$ & -0.260 \\
\hline
\end{tabular}

${ }^{*}$ Correlation is significant at the 0.01 level (2-tailed), ${ }^{*}$ Correlation is significant at the 0.05 level (2-tailed).

of July and October; respective correlation coefficients were 0.364 and 0.321 . A significant negative correlation of Sorghum yield with the mean temperature was found during July to October $(\mathrm{CC}=-0.278)$. There was a significant positive re- 
lationship between Sesame yield and precipitation of July $(\mathrm{CC}=0.335)$. In Afri$\mathrm{ca}$, in addition to the greatest problem of high annual variability of precipitation, the seasonal precipitation also varies drastically as well [13]. Therefore, the climate change in addition to intensified extreme events could influence the crop yield seriously [24]. The variations of temperature, precipitation and atmospheric $\mathrm{CO} 2$ concentration can affect significantly in crop yield [25].

Land use patterns had changed significantly in Gadarif State from 1986 to 2013. The natural vegetation was changed drastically (from 1,538,597 ha in 1986 to $2,459,264$ ha in 2013) to MRA. That leads to extensive loss and degradation of rangeland areas in Gadarif State. Rangeland areas in the state were decreased from 4,342,154 ha in 1986 to 3,473,940 ha in 2013. Forest area and rangeland were reduced due to the expansion of modern mechanized farming to satisfy an increased demand for food due to increased human population [26]. Drastic decrease of natural vegetation areas resulted in progressive loss and degradation of grazing area in most of the Gadarif State [17]. The dynamic rate of vegetation cover, deterioration and decline were terribly speedy over the few decades. In Gadarif State, large tracts of the forests and rangeland were converted to cultivation lands, which made these resources unable to satisfy fodder need for grazing and food security. The overall forest area was reduced because of expansion in modern mechanized farming because of increasing human population. The local community of Gadarif State started illegal cutting of wood to satisfy the local needs of charcoal and other domestic uses, also to boost their income. The nomads do not have any alternative for animal feeding except lopping the trees during the dry season and feeding on young regeneration throughout the rainy season. Current information on the status of vegetation cover and changes in its composition and structure area is restricted, whereas the speed of climatic variations has serious effects on the planning of the management processes in forest reserves. Adversely, the grazing livestock causes notable damage to the refurbishment of the forest.

[27] stated that the conflicts of the farmer-herder for land use caused a major challenge for rural societies as well as Sudan's local authorities. According to [17], the extension of cultivated areas resulted in the drastic decrease in the natural vegetation lands. [10], reported that the Sudan Government's new agricultural policies are focusing more on MRA ventures to increase the grain production through expansion of the cultivated area only, not through increased per unit yield.

\section{Conclusions}

In this study, we have combined the results of impacts of variations in climate and land use policies on food security from 1961 to 2013 to provide a base line for policy makers in Gadrif State, eastern Sudan. We conclude that the policy makers must consider an increase in yield per unit area and utilization of different varieties of fertilizer in addition to the enhancement of grain production 
through expansion of the cultivated area. We recommend the establishment of strong coordination among the concerned sectors such as Forest National Corporation, Mechanized Rain-fed Agriculture, Rangeland management, Wildlife management and Research Institutes to arrive for land use management.

Based on the findings of this study, it is recommended that additional investigations on crops suitable for Gadarif State during drought season should also be carried out for more accurate information, which can be used for crop modeling of appropriate agricultural and water management during a drought cycle. Further studies on drought prediction using future climate scenarios in Gadarif State by utilizing methods presented in this study may be considered for in-depth analysis. Nowadays, climate change has become the major determinant to environment worldwide and most of the environmental changes are associated with the climatic anomalies. To best of our knowledge, a few of studies have so far been conducted to address this global problem.

Agricultural activities in Gadarif State are directly affecting the proportion of forest resources because of change in agricultural ends up, in the unfair exploitation of the forests. Throughout the last four decades, progressive changes within the environment occurred due to the conversion of forest and grassland into cultivated land.

\section{Acknowledgements}

The present research was supported by the National Natural Science Foundation of China, Grant number: [41471058] and [41641003]. The NSFC project Grant number: [91425303], and the SKLCS funding [SKLCS-ZZ-2017].

\section{References}

[1] UNFCCC (1992) United Nation Convention of Climate Change, Rio De Ganero. Article I (Definition). https://unfccc.int/resource/docs/convkp/conveng.pdf

[2] IPCC (2013) Working Group I Contribution to the Fifth Assessment Report of the Intergovernmental Panel on Climate Change the Physical Science Basis, Summary for Policymakers, Climate Change 2013.

https://www.ipcc.ch/pdf/assessment-report/ar5/wg1/WGIAR5_SPM_brochure_en.p $\underline{\mathrm{df}}$

[3] Zakieldeen, S.A. (2007) Vulnerability in Sudan. Tiempo Bulletin 62. http://www.tiempocyberclimate.org

[4] Yagoub, Y.E. (2016) Variation of Drought and Comparative Impact on Vegetation between Qinghai Province and Sudan. Ph.D. Thesis, Northwest Normal University, Lanzhou.

[5] The World Bank (2014) World Development Indicators: Structure of Output. Agriculture, Value Added (\% of GDP). http://wdi.worldbank.org/table/4.2

[6] Magboul, A.M., Elamin, A.M., Khatir, A.A., Ali Babiker, I.A., Abdelmalik, M.A., Ibnoaf, A.A. and El-Hag, F.M. (2015) Assessment of Climate Change and Variability in Butana Region, Sudan. Journal of Natural Resources and Environmental Studies, 3, 1-8.

http://researchpub.org/journal/jonares/number/vol3-no1/vol3-no1-1.pdf 
[7] Idreas, A.E.A. and Abdo Desougi, M. (2015) Potential Impact of Rain Fed Mechanized Farming and Shelter Belts Establishment on the Environment, Case Study Ghadambaliya, Gedaref, Sudan. Journal of Natural Resources and Environmental Studies, 3, 36-43.

http://researchpub.org/journal/jonares/number/vol3-no2/vol3-no2-6.pdf

[8] Adam, A.H.M., Sulfab, H., Al haj, A., Dawood, M.A. and Fangama I.M. (2015) Impact of Mechanized Rain-Fed Agriculture on Some Physical Properties of Clay Soil. Journal of Natural Resources and Environmental Studies, 3, 21-28. http://researchpub.org/journal/jonares/number/vol3-no2/vol3-no2-4.pdf

[9] Lotfie, A.Y. (2013) Survey of Farm Power in the Mechanized Rainfed Agriculture in Gedarif State, Sudan. Journal of Natural Resources and Environmental Studies, 1, 41-48. http://researchpub.org/journal/jonares/number/vol3-no1/vol3-no1-1.pdf

[10] Ayoub, A.T. (1999) Land Degradation, Rainfall Variability and Food Production in the Sahelian Zone of the Sudan. Land Degradation \& Development, 10, 489-500. https://doi.org/10.1002/(SICI)1099-145X(199909/10)10:5<489::AID-LDR336>3.0.C $\mathrm{O} ; 2-\mathrm{U}$

[11] Fahmi, M.K.M., Sanjak, E., Kanninen, M. and Luukkanen, O. (2017) Impacts of Meteorological Drivers and Agricultural Practices on Sorghum, Millet and Sesame Yields in Semi-Arid Lands in Sudan. Journal of Natural Resources and Environmental Studies, 5, 1-11.

http://researchpub.org/journal/jonares/number/vol5-no1/vol5-no1-1.pdf

[12] Meri, J. and Stuart, D.D. (2017) Interrogating Sustainable Productivism: Lessons from the "Almerían Miracle". Land Use Policy, 66, 1-9.

[13] UNDP/UNSO (1997) Aridity Zones and Dryland Populations: An Assessment of Population Levels in the World's Drylands with Particular Reference to Africa. UNDP Office to Combat Desertification and Drought, New York.

[14] Modawi, H.F., Ibrahim, M.E.A. and Hassan, M.M.A. (2015) Use of Modis Imagery to Generate Ahistorical Background of Wildland Fire Regime in Southern Part of Gedaref State-Sudan. Journal of Natural Resources and Environmental Studies, 3, 38-45.

[15] Elhag, M.M. (2006) Causes and Impact of Desertification in the Butana Area of Sudan. PhD Thesis, University of the Free State, Bloemfontein.

[16] Larsson, H. (1996) Relationships between Rainfall and Sorghum, Millet and Sesame in the Kassala Province, Eastern Sudan. Journal of Arid Environments, 3, 211-223. http://researchpub.org/journal/jonares/number/vol3-no3/vol3-no3-6.pdf https://doi.org/10.1006/jare.1996.0018

[17] Sulieman, H.M. and Elagib, N.A. (2012) Implications of Climate, Land-Use and Land-Cover Changes for Pastoralism in Eastern Sudan. Journal of Arid Environments, 85, 132-141.

[18] Yagoub, Y.E., Li, Z.Q., Musa, O.S., Wang, F., Anjum, M.N., Bo, Z. and Ji, D. (2017) Detection of Drought Pattern in Sudan using Standardized Precipitation-Evapotranspiration Index (SPEI). International Journal of Recent Advances in Multidisciplinary Research, 4, 2546-2554.http://www.ijramr.com/archive/201704

[19] Elagib, N.A. and Elhaj, M.M. (2011) Major Climate Indicators of Ongoing Drought in Sudan. Journal of Hydrology, 409, 612-625.

[20] SKAP (1992) Southern Kassala Agricultural Project. Land Use Survey Report (Main Report), Khartoum, 1.

[21] Craig, M.G. (1991) The Agriculture of the Sudan, Center for Agriculture Strategy. University of Reading, Oxford UP, London. 
[22] NAPA (2007) National Adaptation Programme of Action, Republic of the Sudan. Ministry of Environment and Physical Development, Higher Council for Environment and Natural Resources, Khartoum. http://unfccc.int/resource/docs/napa/sdn01.pdf

[23] Reid, R.S., Thornton, P.K. and Kruska, R.L. (2004) Loss and Fragmentation of Habitat for Pastoral People and Wildlife in East Africa: Concepts and Issues. African Journal of Range and Forage Science, 21, 171-184.

https://doi.org/10.2989/10220110409485849

[24] Sivakumar, M.V.K. and Hansen, J. (2007) Climate Prediction and Agriculture: Summary and the Way Forward. In: Advances and Challenges, Springer, Berlin, 306-309. https://link.springer.com/chapter/10.1007\%2F978-3-540-44650-7_1 https://doi.org/10.1007/978-3-540-44650-7

[25] Downing, T.E. (1996) Climate Change and World Food Security NATO ASI Series I. Global Environmental Change, 37, 662.

[26] Yagoub, Y.E., Musa, O.S., Siddig, A.A., Bo, Z., Li, Z. and Wang, F. (2017) Assessing the Impacts of Land Use Changes on Vegetation Cover in Eastern Sudan. International Journal of Research in Agricultural Sciences, 4, 2348-3997.

https://ijras.org/administrator/components/com_jresearch/files/publications/IJRAS 505_FINAL.pdf

[27] Adam, Y.O., Pretzschb, J. and Darrca, D. (2015) Land Use Conflicts in Central Sudan: Perception and Local Coping Mechanisms. Land Use Policy, 42, 1-6. 